\title{
The effects of supplementation with a blend of cinnamaldehyde and eugenol on feed intake and milk production of dairy cows
}

\author{
Emma H. Wall, ${ }^{1}$ Perry H. Doane, $†$ Shawn S. Donkin, $\ddagger$ and David Bravo* \\ *Pancosma SA, CH-1218 Geneva, Switzerland \\ †Archer Daniels Midland Company, Decatur, IL 62526 \\ ‡Department of Animal Sciences, Purdue University, West Lafayette, IN 47907
}

\begin{abstract}
Plant extracts $(\mathrm{PE})$ are naturally occurring chemicals in plants, and many of these molecules have been reported to influence production efficiency of dairy and beef animals. Two experiments were conducted to determine the effect of a PE additive (CE; an encapsulated blend of cinnamaldehyde and eugenol) on the milk production performance of lactating dairy cows across a range of doses. In experiment 1, 32 Holstein multiand primiparous dairy cows in mid-lactation were assigned to no additive or supplementation with CE (350 $\mathrm{mg} / \mathrm{d} ; \mathrm{n}=16 \mathrm{cows} /$ treatment) for $6 \mathrm{wk}$. In experiment 2, 48 Holstein multi- and primiparous dairy cows were assigned to no additive or supplementation with $\mathrm{CE}$ (200, 400, or $600 \mathrm{mg} / \mathrm{d} ; \mathrm{n}=12$ animals/treatment) for 8 wk. A 1-wk covariate period was included in both experiments. In both experiments, individual dry matter intake (DMI), milk production, milk composition, and somatic cell count were recorded daily. In experiment 1, CE was associated with an increase in DMI in both parity groups but an increase in milk production of multiparous cows only. In experiment 2 , milk yield of multiparous cows was decreased at the 2 highest doses, whereas milk yield of primiparous cows was increased at the low and high doses of $\mathrm{CE}$. These responses were accompanied by similar changes in DMI; therefore, CE did not affect feed efficiency. We observed no effect of $\mathrm{CE}$ on SCC or milk composition; however, treatment by parity interactions were detected for each of these variables that have not been described previously. Based on the results of these experiments, we conclude that a blend of cinnamaldehyde and eugenol can increase DMI and milk production in lactating dairy cows. In addition, environmental factors appear to influence the response to $\mathrm{CE}$, including dose and parity, and these should be explored further.
\end{abstract}

Received January 2, 2014

Accepted June 7, 2014.

${ }^{1}$ Corresponding author: emma.wall@pancosma.ch
Key words: dairy cow, feed additive, phytonutrient, plant extract

\section{INTRODUCTION}

One of the ways to improve milk production efficiency of dairy cows is to promote the efficient use of nutrients by rumen microbes and to minimize energy and protein losses during fermentation (Bauman et al., 1985; VandeHaar, 1998). The use of feed additives such as ionophore antibiotics (monensin) has proven to be a successful approach to increasing energy and protein utilization in the rumen, and to improving production efficiency of dairy animals (Sprott et al., 1988; Duffield et al., 2008a,b,c). The inclusion of antibiotics (including monensin) in animal feeds, however, is receiving increased criticism because of the potential for antibiotic residues and resistant strains of bacteria (Russell and Mantovani, 2002; Oliver et al., 2011). Therefore, recent efforts have been made to identify alternatives to antibiotics that can increase production efficiency of livestock, and some plant extracts (PE) appear to be potential candidates.

Plant extracts are naturally occurring chemicals synthesized by a variety of plant species. Many PE have antibacterial, antifungal, and antimicrobial properties designed to protect the plant of origin (Lewinsohn et al., 1991; Phillips and Croteau, 1999). In both dairy and beef production systems, there is interest in using $\mathrm{PE}$ as alternatives to antibiotics during disease (Bampidis et al., 2006) and as enhancers of feed efficiency (Benchaar et al., 2007; Santos et al., 2010; Tager and Krause, 2011; Tekippe et al., 2013). Several PE, including garlic oil, cinnamaldehyde (from cinnamon), and eugenol (from cloves), have been reported to influence rumen fermentation in vitro (Calsamiglia et al., 2007). Therefore, the potential may exist to use these molecules in dairy production systems to improve the efficiency of rumen fermentation to optimize milk production.

Importantly, the effects of many $\mathrm{PE}$ appear to be dose, diet, and $\mathrm{pH}$ dependent (Calsamiglia et al., 2007), 
indicating that the source and dose of supplement provided, feeding management, and physiological state of the animal could affect the response of the animal to supplementation with a particular PE. With respect to dose, there are optimal doses for PE-based additives; if these doses are exceeded, negative effects might be observed. For example, the strong antimicrobial activity of thymol has been associated with varying effects on rumen fermentation in vitro, and this may be due to the fine line between an optimum and a toxic dose (Castillejos et al., 2006).

Several investigations have been conducted to determine the effect of various $\mathrm{PE}$ on production performance of dairy cows (Benchaar et al., 2007; Spanghero et al., 2009; Tassoul and Shaver, 2009; Santos et al., 2010; Tager and Krause, 2011; Tekippe et al., 2013). Feeding a blend of thymol, eugenol, vanillin, guaiacol, and limonene has been shown to increase DMI and FCM of lactating dairy cows fed a moderate dose (600 $\mathrm{mg} / \mathrm{d}$; Kung et al., 2008), whereas at greater doses it had no effect on intake or production but increased milk lactose content and rumen $\mathrm{pH}(750 \mathrm{mg} / \mathrm{d}$; Benchaar et al., 2007) or increased rumen $\mathrm{pH}$ alone (2 $\mathrm{g} / \mathrm{d}$; Benchaar et al., 2006). In another study, feeding a high dose $(1.2 \mathrm{~g} / \mathrm{d})$ of that same blend of $\mathrm{PE}$ was associated with a decrease in DMI and no effect on milk production, indicating improved feed efficiency (Tassoul and Shaver, 2009). Similarly, feeding cows a blend of eugenol, geranyl acetate, and coriander decreased DMI but increased milk fat yield, indicating a shift in energy usage for milk fat synthesis (Santos et al., 2010). Supplementation of lactating dairy cows with a blend of cinnamaldehyde, thymol, and orange peel fed at a moderate dose $(640 \mathrm{mg} / \mathrm{d})$ increased both the fat and protein contents of milk but had no effect on DMI or milk production (Spanghero et al., 2009). A blend of cinnamaldehyde and eugenol fed at moderate doses $(\sim 500 \mathrm{mg} / \mathrm{d})$ had no effect on intake or performance when fed to lactating dairy cows (Tager and Krause, 2011; Tekippe et al., 2013), whereas at a very high dose $(10 \mathrm{~g} / \mathrm{d})$ it negatively affected rumen fermentation (Tager and Krause, 2011). Clearly, many of these experiments confirm the potential effects of $\mathrm{PE}$ to influence lactation performance of dairy cows; however, they also confirm the observations of previous in vitro experiments that the source and dose of the $\mathrm{PE}$ used can have marked effects on the response of the animal. The objective of the experiments herein was to determine the effect of a PE additive (a microencapsulated, rumen-unprotected blend of cinnamaldehyde and eugenol) on the milk production performance of lactating dairy multi- and primiparous cows across a range of doses.

\section{MATERIALS AND METHODS}

Both experiments were conducted at the Purdue University Dairy Cattle Research and Education Center (West Lafayette, IN). The Purdue University Institutional Animal Care and Use Committee approved animal use procedures.

\section{Experiment 1}

Animals and Treatments. Thirty-two Holstein multi- and primiparous cows were selected from the Purdue University Dairy Cattle Research and Education Center, stratified by milk production within parity group (primi- vs. multiparous) and randomly assigned within group to 1 of 2 dietary treatments ( $\mathrm{n}=16$ cows $/$ treatment; each treatment group comprised 5 primiparous and 11 multiparous cows): control (no feed additive) or cinnamaldehyde-eugenol additive (CE; XT$6965,17 \%$ cinnamaldehyde and 28\% eugenol; Pancosma SA, Geneva, Switzerland) for a 6 -wk period, which was preceded by a 1-wk covariate period during which all cows were fed the control diet. At the beginning of the trial cows were $112 \pm 9$ DIM with an average daily milk production of $39.7 \pm 2.1 \mathrm{~kg} / \mathrm{d}$, an average lactation number $2.4 \pm 0.3$, and an average BW of $577 \pm 16 \mathrm{~kg}$.

Cows were housed in individual tie stalls and milked twice daily. One week before the beginning of data collection, all cows were transitioned to the control diets used during the following 6 -wk experiment. Cows were offered a TMR once daily for ad libitum intake (5 to $10 \%$ refusals). Diets contained corn silage, legume haylage, triticale silage, grass and legume hay, roasted soybeans, soyhulls, high-moisture corn, and a proteinmineral-vitamin supplement (Table 1). Individual ration ingredients were sampled weekly and analyzed for DM content, and the data were used to adjust the asfed ration ingredients. Diets were top-dressed with 0.23 $\mathrm{kg}$ of ground corn (control) or ground corn containing $350 \mathrm{mg}$ of the CE additive.

Measurements. Milk production was measured daily at each milking and milk samples were collected weekly from 2 consecutive milkings beginning with the evening milking on d 2, 9, 16, 23, 30, and 37 relative to initiation of treatment to determine effects on milk composition. Evening and morning samples for each sampling day were analyzed separately for percentage milk protein, fat, lactose, SCC, and MUN by Dairy One Laboratories (Ithaca, NY). Daily milk component yields and composition was calculated from milk composition values for each milking sampled and corresponding milk yields for each sampling time. Feed refusals for each cow were weighed daily for calculation 
of individual intakes. Samples of the diet were collected weekly throughout the experiment and composited for analysis by Dairy One, (Ithaca, NY) using wet chemistry techniques (http://dairyone.com/analyticalservices/feed-and-forage/about-forage/).

Energy-corrected milk and 3.5\% FCM for each animal were calculated using methods described by NRC (2001). The equations used were as follows:

$$
\begin{gathered}
3.5 \% \mathrm{FCM}=[(\mathrm{kg} \text { of milk } \times 0.4325) \\
+(\mathrm{kg} \text { of fat } \times 16.216)], \text { and } \\
\mathrm{ECM}=\{[(0.0929 \times \text { fat } \%)+(0.0563 \\
\times \text { true protein } \%)+0.192] \times \mathrm{kg} \text { of milk }\} / 0.68605
\end{gathered}
$$

where $0.68605=$ energy density of milk containing $3.5 \%$ fat and $3.0 \%$ protein. In addition, FCM/DMI and ECM/DMI were calculated to obtain an estimate of milk production efficiency.

\section{Experiment 2}

Animals and Treatments. Forty-eight Holstein multi- and primiparous cows were selected from the Purdue University Dairy Cattle Research and Education Center, blocked by parity and previous milk production and randomly assigned within block to 1 of 4 dietary treatments $(\mathrm{n}=12$ animals/treatment): control (no feed additive); CE-200 [plant extract additive (XT6965; Pancosma SA) fed at $200 \mathrm{mg} / \mathrm{d}$ ]; CE-400 (plant extract additive fed at $400 \mathrm{mg} / \mathrm{d}$ ); or CE-600 (plant extract additive fed at $600 \mathrm{mg} / \mathrm{d}$ ) for an 8-wk period, which was preceded by a 1-wk covariate period during which all cows were fed the control diet. At the beginning of the experiment, cows were $107 \pm 5$ DIM with an average daily milk production of $39.0 \pm 0.72 \mathrm{~kg} / \mathrm{d}$, an average lactation number $2.2 \pm 1.3$, and an average BW of $565 \pm 8.1 \mathrm{~kg}$. Each treatment group comprised 4 primiparous and 8 multiparous cows.

Cows were housed in individual tie stalls and milked twice daily. One week before the beginning of data collection, all cows were transitioned to the control diets used during the following 8-wk experiment. Cows were offered a TMR once daily for ad libitum intake ( 5 to $10 \%$ refusals). The diet consisted of corn silage, legume haylage, legume hay, roasted soybeans, soyhulls, soybean meal, high-moisture corn, and a protein-mineralvitamin supplement (Table 1). Individual ration ingredients were sampled and analyzed weekly as described for experiment 1 . Treatments were administered as a top-dress included with ground corn and fed at a rate of $0.23 \mathrm{~kg} / \mathrm{d}$ designed to deliver $0,200,400$, or 600 $\mathrm{mg} / \mathrm{d}$ of additive (XT-6965, Pancosma SA).
Table 1. Ingredient and chemical composition of the basal diet fed to cows in each experiment (DM basis)

\begin{tabular}{lcc}
\hline Item & Experiment 1 & Experiment 2 \\
\hline Ingredient (\%) & & \\
Corn silage & 26.70 & 32.82 \\
High moisture corn & 13.50 & 7.15 \\
Dry shell corn & - & 6.12 \\
Triticale silage & 7.70 & - \\
Alfalfa hay & 8.50 & 5.46 \\
Alfalfa haylage & 17.60 & 16.91 \\
Roasted soybeans & 7.20 & 1.88 \\
Soyhulls & 3.40 & 6.44 \\
Soybean meal & - & 6.24 \\
Fishmeal & - & 0.46 \\
Urea & - & 0.10 \\
ANI supplement ${ }^{1}$ & 15.40 & 16.42 \\
Nutrient composition & & \\
CP (\%) & 17.80 & 17.50 \\
ADF (\%) & 21.73 & 25.20 \\
NDF (\%) & 31.07 & 37.20 \\
NE (Mcal/kg) & 1.72 & 1.63 \\
Ca (\%) & 0.94 & 0.92 \\
P (\%) & 0.39 & 0.40 \\
\hline
\end{tabular}

${ }^{1}$ Supplement supplied by ADM Alliance Nutrition (Quincy, IL) containing $32.26 \%$ cornmeal, $3.55 \%$ corn gluten meal, $10 \%$ soybean meal, 29.59\% Amino Plus (AGP, Ag Processing, Omaha, NE), 4.77\% $\mathrm{CaCO}_{3}, 2 \%$ phosphorus monocal-21, $1.82 \%$ salt, $3.3 \%$ Na sesquicarbonate, $1.88 \%$ DCAD plus potassium carbonate, $0.69 \% \mathrm{KCl}, 0.75 \%$ potassium magnesium sulfate, $0.78 \%$ magnesium oxide, $0.30 \% \mathrm{Se}$ $(0.06 \%), 0.04 \%$ vitamin E $227 \mathrm{kIU} / \mathrm{lb} ., 0.19 \%$ niacin $(99.5 \%), 0.42 \%$ dairy trace mineral premix, $0.04 \%$ premix containing vitamins A and D, $1.37 \%$ Grease MX Choice white (ADM Alliance Nutrition), $5.5 \%$ Enertia (ADM Alliance Nutrition), $0.75 \%$ dry molasses. Nutrient composition $=25.30 \% \mathrm{CP}, 8.29 \%$ fat, $15.14 \%$ RUP, $10.17 \%$ RDP, $3.62 \%$ $\mathrm{ADF}, 5.80 \% \mathrm{NDF}, 1.96 \mathrm{Mcal}$ of $\mathrm{NE}_{\mathrm{L}} / \mathrm{kg}, 3.26 \% \mathrm{Ca}, 0.85 \% \mathrm{P}, 0.75 \%$ $\mathrm{Mg}, 2.58 \% \mathrm{~K}, 1.99 \% \mathrm{NaCl}$.

Measurements. Milk production was recorded daily for each milking. Milk samples were collected weekly from a consecutive evening and morning milking on $\mathrm{d}$ $2,9,16,23,30,37,44$, and 51 relative to initiation of treatment to determine effects of treatment on milk composition. Analysis of milk and feed samples was conducted as described for experiment 1. Calculations of ECM, 3.5\% FCM, FCM/DMI, and ECM/DMI for each animal were performed as described for experiment 1 .

\section{Statistical Analyses}

For both experiments, statistical analyses were performed using a mixed-effects model (version 9.1; SAS Institute Inc., Cary, NC) accounting for the fixed effects of treatment, time, and parity and their interactions on milk production and composition, SCC, DMI, and milk production efficiency (FCM or ECM/DMI). Data from each experiment were analyzed using the following mixed-effects models with repeated measures:

$$
\begin{aligned}
Y_{i j k m}= & \mu+\alpha_{i}\left(X_{i k j}-\bar{X}\right)+\beta_{j}+\gamma_{k}+c_{m}+\alpha \beta_{i j} \\
& +\alpha \gamma_{i k}+\beta \gamma_{j k}+\alpha \beta \gamma_{i j k}+\varepsilon_{i j k m},
\end{aligned}
$$


where $Y_{i j k m}$ represents the dependent variable (DMI, milk yield, milk production efficiency) of cow $m$ assigned to treatment $i ; \mu$ is the overall true mean; $\alpha_{i}$ is the fixed effect of treatment $i ; X_{i k j}-\bar{X}$ is the value of the covariate; $\beta_{j}$ is the fixed effect of time $j ; \gamma_{k}$ is the fixed effect of parity $k ; c_{m}$ is the random effect of cow $m ; \alpha \beta_{i j}$ is the interaction between treatment $i$ and time $j ; \alpha \gamma_{i k}$ is the interaction between treatment $i$ and parity $k ; \beta \gamma_{j k}$ is the interaction between time $j$ and parity $k$; $\alpha \beta \gamma_{i j k}$ is the interaction between treatment $i$, time $j$, and parity $k$; and $\varepsilon_{i j k m}$ is residual error. For each variable, data from wk 1 of the experiment were used as a covariate in the analysis.

For experiment 2, comparison of each treatment mean to the one control mean was performed using Dunnett's test. The dose responsiveness (linear, quadratic, cubic) of the CE treatments was tested using orthogonal contrasts.

\section{RESULTS}

No animals were treated for clinical mastitis during either experiment.

\section{Experiment 1}

The effects of supplementation of mid-lactation dairy cows with $\mathrm{CE}(350 \mathrm{mg} / \mathrm{d})$ on milk production variables are presented in Table 2. We detected a parity by treatment interaction for milk yield $(P<0.01)$ such that milk production was increased in multiparous $(P$ $<0.001)$ but not primiparous cows $(P>0.80)$. Dry matter intake was increased $(P<0.001)$ in $\mathrm{CE}$ cows with no parity by treatment interaction $(P>0.30)$. We observed no effect of CE on SCC, milk fat, lactose, $3.5 \%$ FCM, ECM, or ECM/DMI $(P \geq 0.18)$ although we identified a trend for a decrease in FCM/DMI in $\mathrm{CE}$ cows $(P \geq 0.10)$. Supplementation with $\mathrm{CE}$ was associated with an increase in protein yield and protein percentage $(P<0.01)$. For MUN, we found a parity by treatment interaction $(P<0.01)$ characterized by a decrease in primiparous $(P<0.001)$ but not multiparous $\mathrm{CE}$ cows $(P>0.20)$. No other treatment by parity interactions were detected, and we observed no treatment by time interaction for any variable measured $(P$ $\geq 0.50)$.

\section{Experiment 2}

Supplementation of mid-lactation multi- and primiparous dairy cows with varying doses of $\mathrm{CE}$ was associated with a parity by treatment interaction for milk yield $(P<0.001$; Figure $1 \mathrm{~A})$. In primiparous cows, supplementation with CE-200 and CE-600 in- creased milk yield, whereas milk yield was decreased in the CE-400 group $(P<0.001)$. In multiparous cows, milk production was decreased in both the CE-400 and CE-600 groups relative to that in control cows $(P<$ 0.001). Similarly, changes in DMI in response to treatment were varied and characterized by an interaction between treatment and parity $(P<0.001$; Figure 1B). Dry matter intake was increased in all $\mathrm{CE}$ groups relative to the control group in primiparous cows $(P$ $<0.001)$, whereas it was not affected or was decreased $(\mathrm{CE}-600 ; P<0.001)$ in multiparous cows. The effect of $\mathrm{CE}$ on SCC was also characterized by an interaction between treatment and parity $(P<0.001$; Figure $1 \mathrm{C})$; in primiparous cows, SCC decreased in CE-600 cows only $(P<0.05)$; whereas in multiparous cows, SCC decreased in the CE-200 and CE-400 treatment groups. The effects of varying doses of $\mathrm{CE}$ on milk composition and milk production efficiency are presented in Table 3. With the exception of protein and lactose percentages and milk production efficiency, which were not affected by treatment, we detected significant treatment by parity interactions for all other variables measured $(P<$ 0.01 ; Table 3). Relative to the control treatment, milk fat percentage and yield and 3.5\% FCM were increased in CE-200 primiparous cows $(P<0.05)$, whereas they were decreased in CE-200 multiparous cows $(P<0.01)$, and milk fat yield was decreased in all CE multiparous cows $(P<0.05)$. Milk protein yield was not affected by treatment in primiparous cows $(P \geq 0.20)$, whereas it was decreased in the CE-600 multiparous cows relative to that in control cows $(P<0.01)$. Energy-corrected milk was increased in the CE-600 primiparous cows, whereas it was decreased in all treatment groups in multiparous cows $(P<0.05)$. Milk lactose yield was increased in CE-600 primiparous cows compared with control, whereas it was decreased in CE-600 multiparous cows $(P<0.001)$. Finally, MUN was increased in the CE-600 primiparous cows relative to the control group $(P<0.01)$, whereas it was decreased in the CE600 multiparous cows $(P<0.01)$.

The dose responsiveness (linear, cubic, quadratic) of the effect of $\mathrm{CE}$ treatment on milk production and DMI was tested using orthogonal contrasts and was not significant for either variable $(P \geq 0.20)$.

\section{DISCUSSION}

Several articles have reported on the use of various PE to influence milk production efficiency of lactating dairy cows (Benchaar et al., 2006; Santos et al., 2010; Tager and Krause, 2011; Tekippe et al., 2013). To our knowledge, this is the first report on the use of a PE feed additive across a range of doses in multi- and primiparous animals. 
Table 2. Milk production variables (LSM) of cows in experiment 1

\begin{tabular}{|c|c|c|c|c|}
\hline Item & Control & $\mathrm{CE}^{1}$ & SEM & $P$-value \\
\hline DMI (kg/d) & 21.40 & 22.80 & 0.10 & $<0.001$ \\
\hline \multicolumn{5}{|l|}{ Milk yield $^{2}(\mathrm{~kg} / \mathrm{d})$} \\
\hline All cows & 37.90 & 39.10 & 0.30 & 0.01 \\
\hline Primiparous & 30.26 & 30.14 & 0.30 & 0.80 \\
\hline Multiparous & 40.91 & 42.40 & 0.30 & $<0.001$ \\
\hline $\mathrm{SCC}(\times 1,000$ cells $/ \mathrm{mL})$ & 109.80 & 149.10 & 19.50 & 0.20 \\
\hline Fat $(\%)$ & 3.69 & 3.80 & 0.05 & 0.50 \\
\hline Fat $(\mathrm{kg} / \mathrm{d})$ & 1.40 & 1.50 & 0.04 & 0.30 \\
\hline $3.5 \%$ FCM $(\mathrm{kg} / \mathrm{d})$ & 39.90 & 41.13 & 1.60 & 0.30 \\
\hline FCM $/ \mathrm{DMI}(\mathrm{kg} / \mathrm{kg})$ & 1.85 & 1.80 & 0.02 & 0.10 \\
\hline Protein $^{3}(\%)$ & 2.64 & 2.80 & 0.01 & $<0.001$ \\
\hline Protein $^{3}(\mathrm{~kg} / \mathrm{d})$ & 1.00 & 1.10 & 0.02 & 0.01 \\
\hline Lactose $(\%)$ & 4.76 & 4.80 & 0.01 & 0.30 \\
\hline ECM $(\mathrm{kg} / \mathrm{d})$ & 38.50 & 40.05 & 1.45 & 0.18 \\
\hline ECM/DMI $(\mathrm{kg} / \mathrm{kg})$ & 1.79 & 1.75 & 0.02 & 0.18 \\
\hline Lactose $(\mathrm{kg} / \mathrm{d})$ & 1.81 & 1.90 & 0.04 & 0.40 \\
\hline \multicolumn{5}{|l|}{$\mathrm{MUN}^{2}(\mathrm{mg} / \mathrm{dL})$} \\
\hline All cows & 12.05 & 11.50 & 0.15 & 0.03 \\
\hline Primiparous & 12.40 & 10.60 & 0.20 & $<0.001$ \\
\hline Multiparous & 12.10 & 12.43 & 0.20 & 0.20 \\
\hline
\end{tabular}

In experiment 1, CE was associated with an increase in milk yield in multiparous cows, whereas a decrease was observed in experiment 2 . It is possible that the different doses used in these experiments may represent an important source of variation in the milk yield response. Similar inconsistencies associated with varying doses of another PE product have been reported (Benchaar et al., 2006, 2007; Kung et al., 2008; Tassoul and Shaver, 2009). Although additional experiments are needed to determine the optimum dose of $\mathrm{CE}$ in dairy cows across various stages of lactation, the results of the current study indicate that the optimum dose of $\mathrm{CE}$ for multiparous lactating dairy cows in early to mid lactation is $350 \mathrm{mg} / \mathrm{d}$ because negative effects were observed at lower and higher doses. In agreement with our observations, Tager and Krause (2011) and Tekippe et al. (2013) reported that a dose of 500 to $525 \mathrm{mg} / \mathrm{d}$ of $\mathrm{CE}$ had no effect on milk production. In contrast to multiparous cows, primiparous cows responded to treatment with an increase in milk yield only at the low (200 mg/d) and high $(600 \mathrm{mg} / \mathrm{d})$ doses.

The mechanism underlying the dose responsiveness of $\mathrm{CE}$ - and the effect of parity on the optimum dose of $\mathrm{CE}$ - is unclear; however, based on in vitro experiments (Calsamiglia et al., 2007), it is possible that rumen fermentation was differentially affected across the dose range and this influenced the milk production response. Based on in vitro rumen fermentation experiments, eugenol has been observed to improve VFA production and nitrogen utilization by the rumen (Calsamiglia et al., 2007). In addition, cinnamaldehyde consistently decreases the acetate:propionate ratio via increased propionate, decreased acetate, or both, depending on the experimental conditions (Calsamiglia et al., 2007). Importantly, the results of in vitro fermentation experiments are not always representative of what occurs in vivo (Hristov et al., 2012), and the doses used for in vitro experiments are usually much greater than what would be administered to the animal (Calsamiglia et al., 2007). Therefore, it is important to confirm observations from in vitro experiments and determine optimum dosage using animal models. In dairy cows, the effects of CE on rumen fermentation are less clear. Tekippe et al. (2013) reported that CE fed at $525 \mathrm{mg} / \mathrm{d}$ to lactating dairy cows had only moderate effects on rumen fermentation and decreased the acetate:propionate ratio in 1 of 2 experiments with no effect on rumen protozoa. In both experiments, NDF digestibility was increased with CE (Tekippe et al., 2013). These responses, however, were not accompanied by increased DMI or milk production; therefore, the functional implications of these effects remain unclear. Although we did not investigate the population of ruminal bacterial strains in the current study, it is important to acknowledge that the doses of PE used in vivo are far below the dose required for bactericidal activity (Friedman et al., 2002). Therefore, it is unlikely that the mechanism of action by which $\mathrm{CE}$ influences milk production is simply via alteration of the rumen microbial population. Alternatively, the mechanism by which PE can 

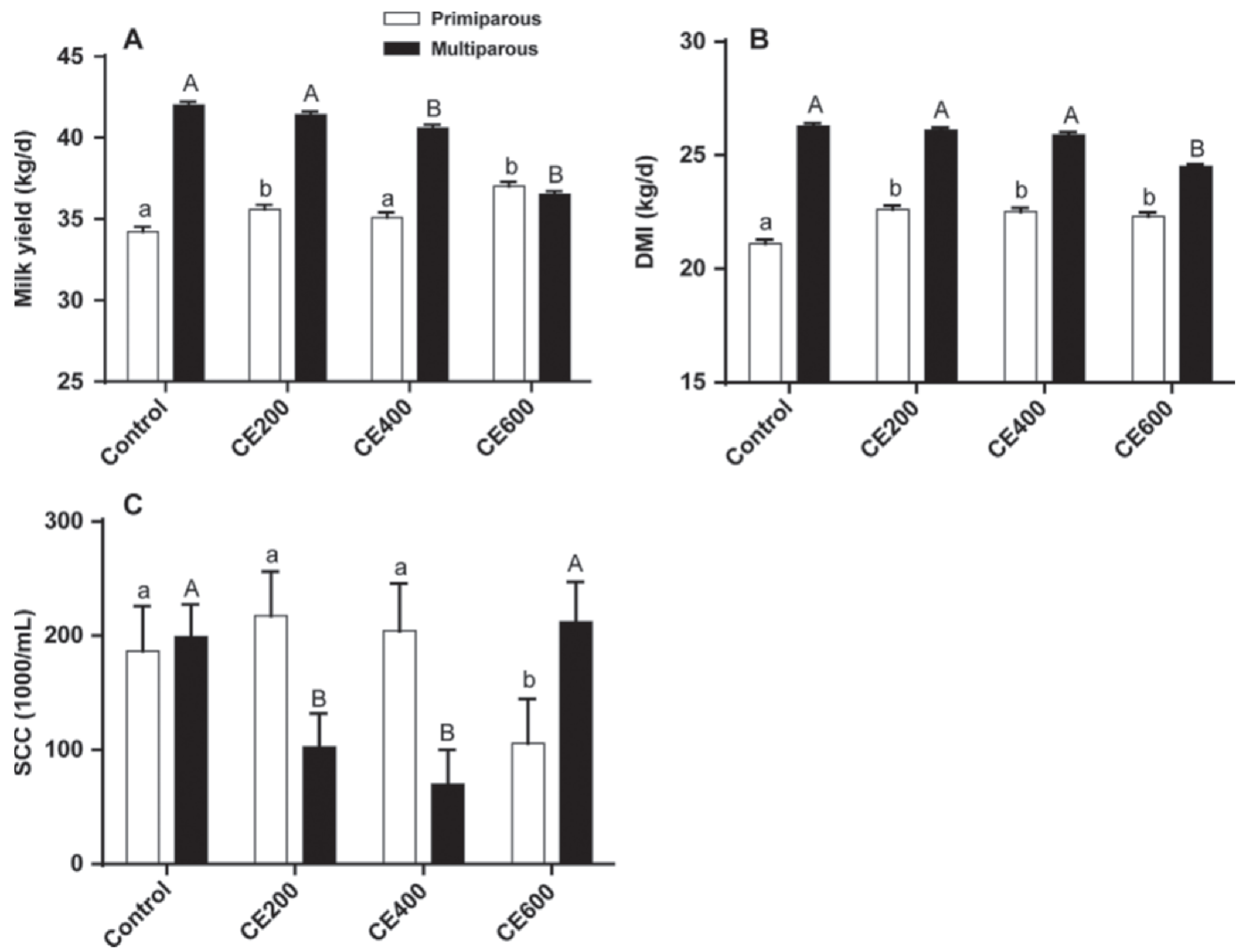

Figure 1. The effect of feeding various doses of a plant extract blend of cinnamaldehyde and eugenol (CE) on (A) milk production, (B) DMI, and (C) SCC of lactating primi- and multiparous cows (experiment 2). Means for primiparous (a,b) and multiparous (A,B) cows with different letters differ from control (Dunnett's adjusted $P<0.05$ ). For all variables, we found a significant treatment by parity interaction $(P<0.001$ ).

influence dairy cow performance might be at a systemic (metabolic or immune) level, independent of rumen function. Indeed, abomasal infusion of some PE have elicited immune responses in dairy cows (Oh et al., 2013); therefore, it is possible that the effects of some $\mathrm{PE}$ are mediated postruminally, perhaps at the level of the lower gut. However, it is unknown how much $\mathrm{CE}$, if any, escapes the rumen and reaches the lower digestive tract. Follow-up experiments designed to investigate the rumen stability of $\mathrm{CE}$ and the effect of CE across a range of doses on rumen fermentation, fiber digestibility, metabolism, and immunity are warranted.

In both experiments, we detected a parity by treatment interaction for milk yield characterized by an increase in milk yield of multiparous cows only at a moderate dose $(350 \mathrm{mg} / \mathrm{d})$ and increased milk yield of primiparous cows only at the lowest $(200 \mathrm{mg} / \mathrm{d})$ and highest $(600 \mathrm{mg} / \mathrm{d})$ doses. Therefore, it appears that the optimal dose of CE might depend on the parity of the animal. This is an interesting observation and, to our knowledge, the first report of an interaction between the effect of a $\mathrm{PE}$ on milk production and parity of the lactating cow. It is unclear what caused the differential response, but several possibilities exist. For example, Santos et al. (2010) suggested that PE might cause a shift in energy partitioning to favor milk fat production. If a similar effect occurred with the additive used in the current experiment, we would expect primiparous cows to respond differently due to the fact that they are still partitioning a significant amount of 
Table 3. The effect of feeding various doses of a plant extract blend of cinnamaldehyde and eugenol (CE) on milk composition of lactating primi- and multiparous cows (experiment 2$)^{1}$

\begin{tabular}{|c|c|c|c|c|c|c|}
\hline \multirow[b]{2}{*}{ Item } & \multicolumn{4}{|c|}{ Treatment } & \multirow[b]{2}{*}{ SEM } & \multirow{2}{*}{$\begin{array}{c}P \text {-value } \\
(\text { parity } \times \text { treatment })\end{array}$} \\
\hline & Control & CE 200 & CE 400 & CE 600 & & \\
\hline Fat $(\%)$ & & & & & & 0.003 \\
\hline Primiparous & $3.22^{\mathrm{a}}$ & $3.72^{\mathrm{b}}$ & $3.45^{\mathrm{a}}$ & $3.43^{\mathrm{a}}$ & 0.13 & \\
\hline Multiparous & $3.97^{\mathrm{a}}$ & $3.59^{\mathrm{b}}$ & $3.67^{\mathrm{a}}$ & $3.92^{\mathrm{a}}$ & 0.09 & \\
\hline Fat $(\mathrm{kg} / \mathrm{d})$ & & & & & & $<0.001$ \\
\hline Primiparous & $1.09^{\mathrm{a}}$ & $1.34^{\mathrm{b}}$ & $1.22^{\mathrm{a}}$ & $1.28^{\mathrm{a}}$ & 0.05 & \\
\hline Multiparous & $1.68^{\mathrm{a}}$ & $1.50^{\mathrm{b}}$ & $1.51^{\mathrm{b}}$ & $1.45^{\mathrm{b}}$ & 0.04 & \\
\hline $3.5 \%$ FCM $(\mathrm{kg} / \mathrm{d})$ & & & & & & $<0.001$ \\
\hline Primiparous & $32.62^{\mathrm{a}}$ & $37.25^{\mathrm{b}}$ & $35.10^{\mathrm{a}}$ & $37.00^{\mathrm{b}}$ & 1.13 & \\
\hline Multiparous & $45.53^{\mathrm{a}}$ & $42.44^{\mathrm{b}}$ & $42.33^{b}$ & $39.52^{\mathrm{b}}$ & 0.82 & \\
\hline FCM/DMI $(\mathrm{kg} / \mathrm{kg})$ & & & & & & 0.06 \\
\hline Primiparous & 1.60 & 1.70 & 1.60 & 1.70 & 0.05 & \\
\hline Multiparous & 1.73 & 1.64 & 1.64 & 1.62 & 0.03 & \\
\hline Protein $^{2}(\%)$ & & & & & & 0.3 \\
\hline Primiparous & 2.99 & 2.85 & 2.93 & 2.99 & 0.05 & \\
\hline Multiparous & 2.87 & 2.91 & 2.92 & 2.94 & 0.03 & \\
\hline $\operatorname{Protein}^{2}(\mathrm{~kg} / \mathrm{d})$ & & & & & & $<0.001$ \\
\hline Primiparous & 1.03 & 1.02 & 1.04 & 1.12 & 0.03 & \\
\hline Multiparous & $1.20^{\mathrm{a}}$ & $1.21^{\mathrm{a}}$ & $1.20^{\mathrm{a}}$ & $1.09^{\mathrm{b}}$ & 0.02 & \\
\hline ECM (kg/d) & & & & & & $<0.001$ \\
\hline Primiparous & $32.86^{\mathrm{a}}$ & $36.60^{\mathrm{a}}$ & $34.95^{\mathrm{a}}$ & $37.04^{\mathrm{b}}$ & 1.04 & \\
\hline Multiparous & $44.50^{\mathrm{a}}$ & $42.00^{\mathrm{b}}$ & $41.86^{\mathrm{b}}$ & $38.95^{\mathrm{b}}$ & 0.77 & \\
\hline ECM/DMI $(\mathrm{kg} / \mathrm{kg})$ & & & & & & 0.10 \\
\hline Primiparous & 1.61 & 1.66 & 1.59 & 1.70 & 0.04 & \\
\hline Multiparous & 1.69 & 1.62 & 1.62 & 1.60 & 0.03 & \\
\hline Lactose (\%) & & & & & & 0.06 \\
\hline Primiparous & 4.80 & 4.91 & 4.81 & 4.90 & 0.04 & \\
\hline Multiparous & 4.76 & 4.68 & 4.76 & 4.69 & 0.03 & \\
\hline Lactose $(\mathrm{kg} / \mathrm{d})$ & & & & & & $<0.001$ \\
\hline Primiparous & $1.65^{\mathrm{a}}$ & $1.77^{\mathrm{a}}$ & $1.70^{\mathrm{a}}$ & $1.84^{\mathrm{b}}$ & 0.05 & \\
\hline Multiparous & $2.01^{\mathrm{a}}$ & $1.96^{\mathrm{a}}$ & $1.96^{\mathrm{a}}$ & $1.73^{\mathrm{b}}$ & 0.03 & \\
\hline MUN (mg/dL) & & & & & & $<0.001$ \\
\hline Primiparous & $12.90^{\mathrm{a}}$ & $12.30^{\mathrm{a}}$ & $13.55^{\mathrm{a}}$ & $14.90^{\mathrm{b}}$ & 0.40 & \\
\hline Multiparous & $13.70^{\mathrm{a}}$ & $13.38^{\mathrm{a}}$ & $12.79^{\mathrm{a}}$ & $11.69^{\mathrm{b}}$ & 0.20 & \\
\hline
\end{tabular}

${ }_{\mathrm{a}, \mathrm{b}}$ Means in the same row with different superscripts are different from control (Dunnett's adjusted $P<0.05$ ). ${ }^{1} \mathrm{CE}=$ a microencapsulated blend of $17 \%$ cinnamaldehyde and $28 \%$ eugenol (XT-6965, Pancosma SA, Geneva, Switzerland).

${ }^{2}$ True protein.

energy to skeletal growth (Hoffman and Funk, 1992). In this scenario, however, we would expect primiparous cows to respond negatively compared with multiparous cows, but we observed the opposite effect in experiment 2. Therefore, it is possible that a different mechanism underlies the response of primiparous and multiparous cows to CE. Alternatively, the changes in milk production might simply have been the result of changes in feed intake (Martin and Sauvant, 2002); however, in experiment 1 DMI was increased in both primi- and multiparous cows with no effect of $\mathrm{CE}$ on milk yield in primiparous cows. Evidently, other factors are likely involved.

Dry matter intake was consistently increased in CE primiparous cows across all doses in both experiments. In multiparous animals, we observed an increase in DMI (experiment 1), no effect (experiment 2, low and moderate dose), or a decrease (experiment 2, highest dose). It is unclear how $\mathrm{CE}$ modulates feed intake, but the effect might be partly attributed to the observed apparent improvement in rumen function, increased fiber digestibility, or both (Tekippe et al., 2013). We did not observe a consistent effect of $\mathrm{CE}$ on milk production efficiency in either experiment (i.e., changes in milk yield were accompanied by changes in DMI). Although we did not investigate other indicators of efficiency, such as reproductive function, it is possible that $\mathrm{PE}$ can influence efficiency when used for a longer duration. A full-lactation experiment is needed to determine the long-term effect of $\mathrm{PE}$ on production and reproductive performance. Indeed, the treatment lengths in experiments conducted to date have been as short as $21 \mathrm{~d}$ (Yang et al., 2007; Tager and Krause, 2011) and the longest was 15 wk (Tassoul and Shaver, 2009).

Somatic cell count was not consistently affected by $\mathrm{CE}$. In agreement with our observations, previous 
experiments investigating other PE (Benchaar et al., 2007; Spanghero et al., 2009; Santos et al., 2010) or the one used in the current study (Tager and Krause, 2011; Tekippe et al., 2013) reported no effect of PE supplementation on SCC. In experiment 2, however, we detected a treatment by parity interaction such that SCC was markedly decreased in multiparous but not primiparous cows. It is unclear why this response was observed in experiment 2 (SCC decreased in cows at doses of 200 and $400 \mathrm{mg} / \mathrm{d})$, but CE $(350 \mathrm{mg} / \mathrm{d})$ had no effect in experiment 1 . In addition to dose, an environmental factor that might influence the response to CE may be baseline SCC or the "risk" of mammary infection present during the experiment. The SCC of control cows in experiment 2 was almost twice that of control cows in experiment 1, despite use of the same research facility for both experiments. Cleanliness of the environment has been shown to influence the response of poultry animals to PE (Pirgozliev et al., 2013); however, in the current experiment, we observed no relationship between baseline SCC and the milk yield response to $\mathrm{CE}$ (data not shown).

Milk composition was not affected by CE except for an increase in milk protein yield and protein percentage and a treatment by parity interaction for MUN in experiment 1 . In experiment 2, cows fed $600 \mathrm{mg} / \mathrm{d} \mathrm{CE}$ produced less milk protein than did control cows. With the exception of milk protein and lactose percentages, we observed a significant treatment by parity interaction on all milk components measured in experiment 2 . For example, milk fat yield and percentage and FCM were increased in primiparous cows fed $200 \mathrm{mg} / \mathrm{d}$ of $\mathrm{CE}$, whereas they were decreased in multiparous cows. At the highest dose $(600 \mathrm{mg} / \mathrm{d})$, milk lactose production and MUN were increased in primiparous cows but decreased in multiparous cows. Tager and Krause (2011) and Tekippe et al. (2013) reported that CE fed at 500 to $525 \mathrm{mg} / \mathrm{d}$ was not associated with changes in milk composition. This is consistent with our observation that many of the differences we observed were at the low dose $(200 \mathrm{mg} / \mathrm{d})$ or the high dose $(600 \mathrm{mg} / \mathrm{d})$ but not the intermediate dose $(400 \mathrm{mg} / \mathrm{d})$. Other PE have been associated with increased milk lactose yield (Benchaar et al., 2007), increased milk fat yield (Santos et al., 2010), or increased milk fat and protein yields (Spanghero et al., 2009). Those findings, taken together with the results of the current study, clearly show that $\mathrm{PE}$ can alter milk composition. The mechanism underlying this effect is unclear; however, as proposed by Santos et al. (2010), this effect could be the result of a shift in energy partitioning that alters milk component synthesis. In agreement, we observed treatment by parity interactions for MUN in both experiments and for fat and protein yields in experiment 2. When taken together, these findings indicate a possible differential CE-induced shift in energy and nutrient partitioning in primiparous and multiparous cows.

Interestingly, a positive milk yield response to supplementation with $\mathrm{CE}$ was often accompanied by no change in MUN (i.e., when MUN was affected, we found either no effect or a decrease in milk yield in response to $\mathrm{CE}$ ). This indicates that protein status (requirements, nitrogen availability, or metabolism) of the animal might predict the response to CE. The existence of such a relationship, as well as the underlying mechanisms and the effects of parity and dose, should be explored further.

We conclude that supplementation with a blend of cinnamaldehyde and eugenol can increase DMI and milk production in lactating dairy cows. In addition, factors such as dose and parity appear to influence the response to the additive and these warrant further investigation.

\section{ACKNOWLEDGMENTS}

Financial support and technical assistance was provided by Pancosma SA (Geneva, Switzerland) and by Archer Daniels Midland Company (Decatur, IL).

\section{REFERENCES}

Bampidis, V. A., V. Christodoulou, P. Florou-Paneri, and E. Christaki. 2006. Effect of dried oregano leaves versus neomycin in treating newborn calves with colibacillosis. J. Vet. Med. A Physiol. Pathol. Clin. Med. 53:154-156.

Bauman, D. E., S. N. McCutcheon, W. D. Steinhour, P. J. Eppard, and S. J. Sechen. 1985. Sources of variation and prospects for improvement of productive efficiency in the dairy cow: A review. J. Anim. Sci. 60:583-592.

Benchaar, C., H. V. Petit, R. Berthiaume, D. R. Ouellet, J. Chiquette, and P. Y. Chouinard. 2007. Effects of essential oils on digestion, ruminal fermentation, rumen microbial populations, milk production, and milk composition in dairy cows fed alfalfa silage or corn silage. J. Dairy Sci. 90:886-897.

Benchaar, C., H. V. Petit, R. Berthiaume, T. D. Whyte, and P. Y. Chouinard. 2006. Effects of addition of essential oils and monensin premix on digestion, ruminal fermentation, milk production, and milk composition in dairy cows. J. Dairy Sci. 89:4352-4364.

Calsamiglia, S., M. Busquet, P. W. Cardozo, L. Castillejos, and A. Ferret. 2007. Invited review: Essential oils as modifiers of rumen microbial fermentation. J. Dairy Sci. 90:2580-2595.

Castillejos, L., S. Calsamiglia, and A. Ferret. 2006. Effect of essential oil active compounds on rumen microbial fermentation and nutrient flow in in vitro systems. J. Dairy Sci. 89:2649-2658.

Duffield, T. F., A. R. Rabiee, and I. J. Lean. 2008a. A meta-analysis of the impact of monensin in lactating dairy cattle. Part 1. Metabolic effects. J. Dairy Sci. 91:1334-1346.

Duffield, T. F., A. R. Rabiee, and I. J. Lean. 2008b. A meta-analysis of the impact of monensin in lactating dairy cattle. Part 2. Production effects. J. Dairy Sci. 91:1347-1360.

Duffield, T. F., A. R. Rabiee, and I. J. Lean. 2008c. A meta-analysis of the impact of monensin in lactating dairy cattle. Part 3. Health and reproduction. J. Dairy Sci. 91:2328-2341.

Friedman, M., P. R. Henika, and R. E. Mandrell. 2002. Bactericidal activities of plant essential oils and some of their isolated constitu- 
ents against Campylobacter jejuni, Escherichia coli, Listeria monocytogenes, and Salmonella enterica. J. Food Prot. 65:1545-1560.

Hoffman, P. C., and D. A. Funk. 1992. Applied dynamics of dairy replacement growth and management. J. Dairy Sci. 75:2504-2516.

Hristov, A. N., C. Lee, R. Hristova, P. Huhtanen, and J. L. Firkins. 2012. A meta-analysis of variability in continuous-culture ruminal fermentation and digestibility data. J. Dairy Sci. 95:5299-5307.

Kung, L. Jr., P. Williams, R. J. Schmidt, and W. Hu. 2008. A blend of essential plant oils used as an additive to alter silage fermentation or used as a feed additive for lactating dairy cows. J. Dairy Sci. 91:4793-4800.

Lewinsohn, E., M. Gijzen, T. J. Savage, and R. Croteau. 1991. Defense mechanisms of conifers: Relationship of monoterpene cyclase activity to anatomical specialization and oleoresin monoterpene content. Plant Physiol. 96:38-43.

Martin, O., and D. Sauvant. 2002. Metaanalysis of input/output kinetics in lactating dairy cows. J. Dairy Sci. 85:3363-3381.

NRC. 2001. Nutrient Requirements of Dairy Cattle. 7th rev. ed. Natl. Acad. Press, Washington, DC

Oh, J., A. N. Hristov, C. Lee, T. Cassidy, K. Heyler, G. A. Varga, J. Pate, S. Walusimbi, E. Brzezicka, K. Toyokawa, J. Werner, S. S. Donkin, R. Elias, S. Dowd, and D. Bravo. 2013. Immune and production responses of dairy cows to postruminal supplementation with phytonutrients. J. Dairy Sci. 96:7830-7843.

Oliver, S. P., S. E. Murinda, and B. M. Jayarao. 2011. Impact of antibiotic use in adult dairy cows on antimicrobial resistance of veterinary and human pathogens: A comprehensive review. Foodborne Pathog. Dis. 8:337-355.

Phillips, M. A., and R. B. Croteau. 1999. Resin-based defenses in conifers. Trends Plant Sci. 4:184-190.

Pirgozliev, V., D. Bravo, and S. P. Rose. 2013. Rearing conditions influence nutrient availability of plant extracts supplemented di- ets when fed to broiler chickens. J. Anim. Physiol. Anim. Nutr. (Berl.) http://dx.doi.org/10.1111/jpn.12119.

Russell, J. B., and H. C. Mantovani. 2002. The bacteriocins of ruminal bacteria and their potential as an alternative to antibiotics. J. Mol. Microbiol. Biotechnol. 4:347-355.

Santos, M. B., P. H. Robinson, P. Williams, and R. Losa. 2010. Effects of addition of an essential oil complex to the diet of lactating dairy cows on whole tract digestion of nutrients and productive performance. Anim. Feed Sci. Technol. 157:64-71.

Spanghero, M., P. H. Robinson, C. Zanfi, and E. Fabbro. 2009. Effect of increasing doses of a microencapsulated blend of essential oils on performance of lactating primiparous dairy cows. Anim. Feed Sci. Technol. 153:153-157.

Sprott, L. R., T. B. Goehring, J. R. Beverly, and L. R. Corah. 1988. Effects of ionophores on cow herd production: A review. J. Anim. Sci. $66: 1340-1346$

Tager, L. R., and K. M. Krause. 2011. Effects of essential oils on rumen fermentation, milk production, and feeding behavior in lactating dairy cows. J. Dairy Sci. 94:2455-2464.

Tassoul, M. D., and R. D. Shaver. 2009. Effect of a mixture of supplemental dietary plant essential oils on performance of periparturient and early lactation dairy cows. J. Dairy Sci. 92:1734-1740.

Tekippe, J. A., R. Tacoma, A. N. Hristov, C. Lee, J. Oh, K. S. Heyler, T. W. Cassidy, G. A. Varga, and D. Bravo. 2013. Effect of essential oils on ruminal fermentation and lactation performance of dairy cows. J. Dairy Sci. 96:7892-7903.

VandeHaar, M. J. 1998. Efficiency of nutrient use and relationship to profitability on dairy farms. J. Dairy Sci. 81:272-282.

Yang, W. Z., C. Benchaar, B. N. Ametaj, A. V. Chaves, M. L. He, and T. A. McAllister. 2007. Effects of garlic and juniper berry essential oils on ruminal fermentation and on the site and extent of digestion in lactating cows. J. Dairy Sci. 90:5671-5681. 